\title{
EMPIRICAL INVESTIGATION OF RISK MANAGEMENT PRACTICES
}

\author{
Vilma Nasteckiené $\dot{e}^{*}$
}

Received: 2.5. 2021

Preliminary communication

Accepted: 7. 9. 2021

UDC 005.334

DOI https://doi.org/10.30924/mjcmi.26.2.5

\begin{abstract}
In risk management research, dealing with known risks and helping companies foresee new risks are areas for subject matter experts. In practice, risk management is often perceived as a set of formal tools and procedures that must be delegated to the professionals. Despite this overall perception of risk, general managers, department managers, and other senior or line managers in organizations deal with questions associated with risk on a daily basis. They are, therefore, sometimes-even without consciously realizing it-involved in risk management practices. This article aims to analyze 'managers' involvement in risk management by empirically exploring how
\end{abstract}

Abstract

\section{INTRODUCTION}

Risk management is a hot topic that has recently been gaining more attention due to the various crises that have hit the world in recent years. Organizations use a variety of tools and methods, such as crisis management, business continuity management, risk management, performance management, operations management, and other methods, to help managers deal with risk in their day-to-day operations and in exceptional circumstances. Scholars do not agree on whether risk management should be integrated into or kept separate from business performance management (Arena and Arnaboldi, 2014). The research managers identify, assess, and respond to risks. Based on thematic analysis of observational and interview data, management practices used to manage risks were identified, and risk management as a non-linear process that is anchored on the strategic and operational levels and supported by learning from failures was defined. Two different ways of risk management can co-exist in an organization as a result of formal Enterprise Risk Management implementation.

Keywords: risk management practices, enterprise risk management, risk, managers, management practices.

in the Enterprise Risk Management (ERM) field initiated a broader discussion about the management's role in risk management (Bromiley et al., 2015; Palermo et al., 2017; Ring et al., 2016; Wardman \& Mythen 2016); however, the field is still fragmented. Some studies have aimed to explain how managers are involved in risk identification (Maguire \& Hardy, 2014; Bednarek et al., 2019; Hardy et al. 2020), risk assessment (Bromiley et al. 2015; Maguire \& Hardy, 2013, Ring et al., 2016), and risk response (Woods, 2008; Hardy et al., 2020), but no systematic investigation into the management's role in risk management practices has been acknowledged by ERM researchers themselves (Palermo et al.,

\footnotetext{
Vilma Nasteckienė, PhD candidate, ISM University of Economics and Management, Arklių str. 18, Vilnius LT01305, Lithuania, Phone: +370 686 34532, E-mail: vilma.nasteckiene@ism.lt
} 


\section{Journal of Contemporary Management Issues}

2017). From an enterprise-wide risk management research perspective, risk management practices have undergone conceptual analysis, but they are currently under-researched empirically and theory is disconnected from the field (Bromiley et al., 2015; Power, 2016; Hardy et al., 2020; McShane, 2017).

Therefore, this research systematically investigates how managers are involved in risk management practices. The study also aims to empirically elaborate on how managers identify, assess, and respond to the risk in their everyday activities. The paper consists of the following parts: the theoretical background reveals the current understanding of risk management practices and gaps in ERM research; the methodology section presents the research framework, case companies, and the data collection and analysis process; the findings section reveals two different ways of managing risk in the case companies; then there is the discussion section and, finally, the conclusion.

When asked about risk, managers talk about business, performance, objectives, and obstacles. They solve problems, improve processes, and experience failures. Near misses, mistakes, and unresolved problems are offset by growth and business development in a normal situation. Some organizations perform better than others in normal and critical situations; however, adopting visible risk management tools is not protecting them from major failures. This article extends the understanding of the risk management practices that managers use every day based on the results of qualitative research. A systemic analysis of what managers are discussing and doing about risk in their regular performance management meetings can be used to study the patterns of daily risk management practice in other organizations. Empirically based knowledge of how managers identify risks using business planning and monitoring; how they assess and discuss the importance of identified risk; and how they respond to it by assigning responsibility for it to someone and/or solving the problem can be useful in developing risk management tools to practically support strategy deployment and business management at both the strategic and operational levels.

\section{THEORETICAL BACKGROUND}

Despite multiple surveys on risk management and the emerging concepts, the definition of risk remains vague as it is still developing and changing over time. On the one hand, it is defined broadly as a shared perception of a possible source of harm or benefits in relation to what is expected (Arena et al., 2010; Maguire and Hardy, 2013; Bednarek et al., 2019); on the other hand, risk management is defined more narrowly as a set of tools and practices that help managers to ensure a predictive outcome with limited resources and also to control these achievements (Roethlisberger, 1941; Roethlisberger and Dickson, 2003; Hubbard, 2009; Mikes and Kaplan, 2013, Tereso et al., 2019). Unfortunately, the quantitative or, as defined by Mikes and Kaplan (2013), the "numeric" approach to risk is firmly embedded in risk management tools. As criticized by some ERM scholars (Bromiley et al., 2015; Power, 2016, Hardy et al. 2020), sometimes risk management becomes separated from the daily life of an organization and of the management, as risk is detached from their actual business problems. Therefore, this paper aims to explain how managers are involved in risk management through everyday risk management practices. 
This research is based on a broader perspective of risk management practices in line with Power (2016), Kaplan \& Mikes (2016), Palermo et al. (2017), and others. Risk management practices in this study are defined as repetitive management activities guided by formal procedures and/ or implicit (informal) routines through which organizational actors make sense of risk and respond to it. Risk management is typically explained as the stages of risk identification, risk assessment, and the response to the identified risk. Some scholars include a conclusion phase, as per Boban et al. (2003), but the first three stages are used to categorize the scattered research on risk management practices. The following risk management practices are explored in further chapters: risk identification practices, risk assessment practices, and risk response practices.

\subsection{Risk identification practices}

Risk identification is a stage in which managers detect potential threats to the expected result. Risk identification is closely tied to risk perception-what managers identify as a problem to be mitigated, which constitutes the risk in their practice (Bromiley et al., 2015). Moreover, a perception of the importance of risk can determine the selection and usage of risk management tools, according to Treven et al. (2019).

The analyzed research presents risk identification practices as tools and techniques managers apply at the strategic and operational levels: for example, the development of scenarios or risk workshops (Kaplan and Mikes, 2016; Wardman and Mythen, 2016). Managers in the finance sector use forecasting and modeling practices to define optimal conditions and foresee the risks involved based on experience
(Osman and Mahmoud, 2018; Prioteasa et al., 2020), while planning is a key risk identification practice in project management to detect risks in the early stages of a project (Boban et al., 2003).

Conceptually, managers identify risks by looking for recognizable precedents or questioning existing knowledge (Maguire and Hardy, 2013; Hardy et al., 2020). Arena et al. (2010), Kaplan and Mikes (2016), Bednarek et al. (2019) indicate the importance of sensemaking around risk and of having an aligned understanding of the nature of risk in the risk identification stage. Palermo et al. (2017) identified measures, surveys, and incentives as diagnostic practices and they also highlighted networking and conversation enablers as interactive practices.

At the strategic level, planning and review cycles are scheduled annually or quarterly, and risk identification practices namely risk workshops, scenario discussions, and follow-ups - are usually either aligned with or embedded into the planning and review processes. Kaplan and Mikes (2016) suggest connecting the frequency of risk identification practices to "the velocity of risk evolution", emphasizing the importance of aligning the frequency of risk identification practices with the rhythm of all organizational processes, such as business planning and reviewing. Although regular risk workshops and meetings are part of risk identification practices, a broader view is lacking risk identification in organizational processes and the related management practices, such as, for example, strategy workshops.

At the operational level, risk management, instead of supporting managers' decision-making, as noted by Arena et al. (2010), tends to emphasize compliance and internal control. Overall, risk research lacks 


\section{Journal of Contemporary Management Issues}

empirical data on risk management practices at the operational level. It is unclear how unknown risks, i.e., uncertainties as per Arena et al. (2010), are conceptualized as and converted into manageable risks.

To sum up, risk identification practices are based on diagnostic tools and regular interactive cooperation; and they are related to strategy planning and performance management in organizations; however, risk research provides a fragmented understanding of the risk identification practices at the operational level.

\subsection{Risk assessment practices}

At the risk assessment stage, managers evaluate the importance of the identified risk and decide what to do about it. Considering the fragmented research on risk assessment practices, the previous studies are more often presented from a quantitative rather than a qualitative perspective, while both are important.

A good example of quantitative risk assessment practices can be found in finance, where risk assessment procedures are often standardized and connected with quantitative models or "calculating practice" that can be unfolded through the use of analytical tools to make decisions and assess the relevant information (Bednarek et al. 2019). Although these tools are visible, standardized, and auditable (Ring et al. 2016), the insufficient quality of information and lack of historical data are the limitations of quantitative risk assessment.

The quantitative assessment also disregards more elements, such as values and interests, and turns into a kind of "compliance rationality" (Bednarek et al., 2019; Arena et al., 2010). Qualitative risk assessment practices can therefore be revealed through discussions of causality during risk workshops and analysis of past events. Moreover, risk assessment is tied to the availability of information and risk communication, as "qualitatively, risk depends on what you do and what you know and what you do not know" (Kaplan and Garrick, 1981, p.12). In contrast to calculations, the assessment of information is less objective and may result in a difference between objective measures and a manager's risk assessment (Bromiley et al., 2015).

While some scholars, for example Osman and Mahmoud (2018), still emphasize the documented risks and structured process to define likelihood and impact for each risk, others argue that organizations approach risk and assess riskiness or safety in different ways (Maguire and Hardy, 2013; Bednarek et al., 2019). When different actors use different views to assess risks and do not interact with each other, the risk assessment in an organization does not necessarily correspond to an actual situation.

In summary, risk assessment practices are often limited to a quantitative view. The value of calculative practices is limited by the availability of previous knowledge and facts; nevertheless, it is useful to assess known localized risks. Further empirical research is needed to understand what practices are used by managers to assess risk before making any decisions about risk response.

\subsection{Risk response practices}

Risk response is a stage in which managers apply measures to the risk, i.e., control, reduce or transfer, depending on the decision about how much risk an organization is willing to retain for itself. Risk response practices can have a long-term and a short-term perspective. Hardy et al. (2020) claim risk response results in new ways of organizing risk, such as long-term risk 
management practices. On the other hand, responding to risk in a real-time manner explains short-term risk response practices (Hardy et al., 2020).

In the long-term perspective, managers respond to the identified risks by applying strategic controls and risk controls (Woods, 2008). The integrity of both types of controls is important and should be aligned to focus on the common objective. When organizations employ centralizing, calculating, and diversifying practices, they construct the risk object as abstract and distant (Bednarek et al., 2019), thus preparing for long-term risk response.

Short-term risk response practices are related to decision-making in an organization. Hardy et al. (2020) reveal improvisation as an alternative real-time practice to respond to risk. The underlying question is regarding how decision-making can be organized and integrated into the other risk management practices. Behavioral scientists argue that organization is a way of framing individual risk preferences (Tversky and Kahneman, 1974; Tversky and Fox, 1995). Changes in behavior follow a decisional mindset, which is, as stated by Arena et al. (2010), highly dependent on whether managers perceive risks as real problems or hypothetical scenarios; however, there is a lack of research on how risk enters into the management team's conversations and how an immediate response to risk is practiced by managers in everyday life.

To recap, risk management practices are categorized according to the stages of risk management: identification, assessment, and response. As ERM researchers, such as Bromiley et al. (2015), have indicated, research into how managers are involved in daily risk management is still very scattered; therefore, empirical research is focused on investigating this topic.

\section{METHODS}

\subsection{Research context}

Two organizations, different in several characteristics and having similarities in other characteristics, were chosen for this research as polar case studies (Eisenhardt, 1989; Eisenhardt, 2020). The first organization (hereafter, Company A) is a private mid-sized company working in the field of waste management and logistics, with around 350 employees in total. Company A has no formalized ERM framework but has several specific risk-related procedures - for example, risk management procedures regarding safety at work. The second organization (hereafter, Company B) is a midsized state-owned company with around 450 employees. Company B has a formalized ERM framework, and the managers follow formal risk management processes related to the structure, policies, and other areas of organizing.

\subsection{Data}

The risk management practices of the two companies were investigated by combining two qualitative methods of data collection: observation and interviews. By observing the managers at their meetings, risk management as an accomplishment in realtime as a part of the general management practices was identified. Observational data was extended with information about the events, issues, and risk management practices outside of the meetings (as discussed by the participants at the meetings). Openended interviews with the managers covered the following topics: how they see risk management in their companies and how it is related to their strategic objectives and daily operations; how they choose which problems to be escalated in the management meetings and what happens next; what 


\section{Journal of Contemporary Management Issues}

behavior they expect from their team in relation to risk and what it is now. As a result, more focused information about risk-related practices was received.

The data were collected in two stages. In the first exploratory stage, the researcher attended two daily management meetings to observe the process and establish contact with participants. Initial observation and five informal conversations with the CEOs of both companies and other managers helped develop more focused observation and interview protocols for the main data collection stage. In addition to this, the companies' internal documents related to their risk management procedures were collected and analyzed. During the second stage, the main data collection stage, a series of meetings were recorded (six at Company A and ten at Company B) and interviews with senior managers were conducted (five at Company A, and nine at Company B). Selective transcription for each management meeting ( $\sim 30$ singlespaced pages in total) and a full transcription of the interviews with the senior managers (38 single-spaced pages in total) were prepared.

\subsection{Data analysis}

The data coding and analysis underwent multiple cycles until a structured relationship emerged. At first, the data were explored to make sense of the broader picture by listening to the recorded meetings. This was followed by inductive in-vivo coding of the observation transcripts to identify what the managers do during the meetings to address risk-related matters and what they say that they do outside of the daily meetings. This way, some common perceptions and practices concerning risk management in the organizations were identified. In the final stage, the thematic analysis methodology (Braun \& Clarke, 2006) was followed to structure the initial findings around three themes - the identification of risk, the assessment of risk, and the response to risk - and I identified thirteen risk management practices associated with these three stages of risk management (see Table $1)$.

Analysis revealed that the majority of the practices help accomplish more than one risk management stage: for example, when the managers compared the actual and expected results of a customer service or logistics project, they identified deviations and discussed the causes of underperformance or delays, which constitute risks. At the same time, they would start assessing the risks: for example, discussing how serious the deviations are and what further analysis or actions might be needed to prevent the company from reputational damage from customer complaints or financial impact due to delayed project implementation. In Table 1, the cells that are highlighted with dark gray indicate a practice that is primarily linked to identification (practices 1 to 5), assessment (6 to 9), or response (10 to 13), while lighter gray is used to denote other interactions. Risk management practices were grouped according to their primary function. 
Table 1. Identified risk management practices

\begin{tabular}{|c|c|c|c|}
\hline Risk management practice & Identification & Assessment & Response \\
\hline 1. Setting performance targets and indicators of risk & \multirow{5}{*}{1} & & \\
\hline $\begin{array}{l}\text { 2. Comparing actual and expected results to prevent } \\
\text { risks/reduce impact }\end{array}$ & & & \\
\hline $\begin{array}{l}\text { 3. Planning and reviewing project status to prevent } \\
\text { risk }\end{array}$ & & & \\
\hline 4. Meeting daily as a team & & & \\
\hline 5. Sharing signals within the team & & & \\
\hline 6. Collecting and analyzing risk-related data & & \multirow{4}{*}{2} & \\
\hline 7. Discussing risk-related deviations and obstacles & & & \\
\hline 8. Addressing customer complaints & & & \\
\hline 9. Working with investigation/inspection reports & & & \\
\hline 10. Assigning responsibility & & & \multirow{4}{*}{3} \\
\hline 11. Recording and reporting back & & & \\
\hline 12. Reacting to problems, including firefighting & & & \\
\hline $\begin{array}{l}\text { 13. Defining and improving processes, maintaining } \\
\text { clarity }\end{array}$ & & & \\
\hline
\end{tabular}

Source: Authors.

\section{RESULTS}

\subsection{Risk identification practices}

Risk identification practices include all the management practices related to planning and monitoring performance and potential risks, such as setting performance targets and indicators; comparing the actual and expected results; planning; reviewing status; meeting together; and sharing information. These practices help managers monitor performance results, projects, processes, etc., and ensure they are regularly reviewed and reveal signals of potential risks. Signals can come from the external context-from customers, from competitors, or even in the form of warnings about changing legal requirements - or from an internal context in the form of unstructured information from employees. Through discussing deviations and obstacles, managers can identify potential risks and decide on preventive measures or improvements.

The data analysis revealed a paradox: monitoring helps identify failures and potential risks, but it is not perceived as a form of risk-related communication. During the interviews, the managers I spoke to did not connect performance with risk monitoring - "Nobody thinks whether KPIs and the risk register are somehow related" (M15). Contrary to business results, risk reporting is something that is delegated and reported on quarterly to the group as "our tools are for reporting and escalating risks to group level; we let them [the group management] do with risks what they wish" (M15). Although Company A has not adopted any formal risk management tools, the perception of risk indicators is similar"- "I have never thought about indicators in terms of risk management; we do not have systemic risk-related indicators" (M14). 


\section{Journal of Contemporary Management Issues}

\subsubsection{Setting performance targets and indicators of risk}

The practice of setting performance targets is related to the annual strategic objectives in both companies. Once the financial objectives and business plan are approved and communicated, the indicators for further implementation monitoring are agreed upon within the management team. The study reported that the managers care about indicators, as "I can name KPIs in the middle of the night" (M15). Targets can be set per month or week as indicators of results"if you plan just one new client per week and you cannot preliminarily indicate the name of the client, most likely you will not have an agreement this week" (Meeting 1024). Although the managers do not perceive performance measures as risk indicators, the indicators related to objectives do serve as early warning signals of potential risks.

In company $\mathrm{A}$, the main performance target is their budget. The strategic projects approved by the board become an objective for the management team. These strategic projects are related to strategic risk management. The managers break down the annual targets into monthly targets and weekly targets and assign indicators to monitor performance at the company level. At the lower level, the managers have indicators for daily monitoring. The rhythm of this practice differs across different parts of the organization. In company $\mathrm{B}$, the annual strategy planning cycle produces a business plan, including objectives, KPIs, and a list of strategic projects to be implemented. KPIs are cascaded to the organization to be monitored in daily meetings at all levels of the organization. In addition, risk workshops are held once per year during strategic planning. The implementation of their risk plan is just another objective.

\subsubsection{Comparing the actual and expected results to prevent risks in the future and reduce the impact of failure}

Performance indicators are reviewed in both companies during regular management meetings. Through comparing the actual and expected results, the managers can identify any potential risks"-."I follow the number of visits executed and plan ahead to eliminate that risk" (M12). When the managers decide on preventive actions, they define the expected result. "We have to escalate unused logistics resources and ask commerce to find clients for available resources" (Meeting 1027). By comparing the actual result with the expected result, they can verify whether or not their decision was right" - "for 6-7 months we fall down and cannot stop it ....[silence].... I do not know what to do" (M9). Monitoring and comparing results present a link between risk identification and follow-up, even if action is not taken. Company $\mathrm{B}$ has weekly management meetings. In Company $\mathrm{B}$, performance indicators are reviewed daily. The daily management meeting agenda and content have a vague relationship with the risk register and the risk mitigation plan.

\subsubsection{Planning and reviewing the status of projects to prevent risk}

Both companies have strategic projects approved by the Board. Additionally, projects are initiated in response to changes in legislation or to solve identified problems. The CEOs expect the managers to think and discuss before implementation. The managers need the skills and practice to foresee uncertainties; however, "we are assessing risk within a project, but we are still not very competent while doing this" (M14). While reviewing a project's status, a project manager is obliged to evaluate the situation and share risk-related messages with the team: for example, information 
about a failure to meet a deadline in a logistics project or a delay in an accounting project. Although there is sometimes no response to the problems reported during a meeting, regular reviews help track their status and identify unforeseen risks during implementation.

In Company A, client on-boarding has also become a project. During the planning stage, risks are expected to be identified. The managers review project status and the plans for the week at each weekly meeting. In Company B, the implementation of strategic projects and the risk mitigation plan are reported on a quarterly basis. In addition, the managers have a separate monthly meeting to review project status.

\subsubsection{Meeting daily as a team}

Both companies have regular team meetings at all levels of the organization. Daily and/or weekly meetings as a team are a part of the management's activities to identify risks and problems, monitor performance, exchange information, and engage the team in continuous improvement, as "we have cascaded meetings and prior to the management team meeting, I have a meeting with my team" (M1). By meeting with their teams first, the managers "collect indicators from unit managers before the meeting; we either initiate changes or talk about problems that hurt us today" (M7). The managers value the opportunity to share their problems and experience with their team" - "others might face a similar situation and they are not warned by or learning from my experience" (M17).

In Company A, some managers meet with their teams daily, some managers meet weekly with matrix or project teams, while the management team meets weekly. This difference in rhythm causes delays in escalating information from the team meeting.
In Company B, managers meet with their teams, get updates and insights from employees before the management team meeting, and collect signals and problems that need escalation.

\subsubsection{Sharing signals within the team}

When a manager brings a signal and shares it with other managers, they either expect help from the others or assume that the information will be important to the others. For example, a clear warning message about risk in daily operations is conveyed through signals about mistakes that might be repeated-"with the next serious mistake we can have problems" (Meeting 1017). Some signals come from planning and monitoring activities, others are collected from teams, but they can also come from outside the company. For example, signals about forthcoming changes in legislation are equally important in both companies. The team response is nevertheless important"- "when you receive a signal and know that measures shall be taken, team response and team engagement really motivate to bring signals" (M6).

Company A did not specify "signals" in their meeting agenda; nevertheless, they discussed customer complaints, problem escalation, obstacles, and audit reports as signals related to potential or real risks. Within the management team, the managers share responsibility for bringing signals from defined sources: for example, the head of commerce brings signals from customers or competitors, and the HR manager is responsible for sharing information about safety at work and external inspections. Company $\mathrm{B}$ included signals on the meeting agenda along with other indicators. Signals can come from external sources, i.e., customers, or internal sources, i.e., processes and/ or employees. 


\section{Journal of Contemporary Management Issues}

To sum up, the backbone of risk identification practices are the business planning and monitoring practices that hold twofold importance for risk management-they generate signals by identifying potential risks and risk events, and they aid in the follow-up of risk response. Risk assessment is somehow integrated with risk identification when managers decide they want to deep-dive into the data.

\subsection{Risk assessment practices}

Risk assessment can be hidden in management team discussions without statistical calculations; nevertheless, risk assessment helps managers define which problems and risks can be left unattended and which require an immediate response. Managers assess risk by discussing the riskrelated deviations and obstacles and collecting and analyzing the data related to these risks. As a result, they identify the problems and potential risks that need further attention. If a signal is recognized as significant, it is converted into a task or a problem to be solved. Managers can also decide to accept the risk without taking any corrective actions. When associated with a situation or a problem, a signal helps not only to minimize the consequences but also to initiate the preventive measures needed to avoid a risky situation in the future, as stated during the interview, "we have an agreement that each signal shall produce a twofold outcome, first, there is a solution to the situation-reduction of negative impact-secondly, improvement or actions toward prevention in the future is initiated, however, it is seldom to see both, usually we end up with the first stage" (M3).

\subsubsection{Collecting and analyzing the data related to risk}

In both companies, the managers collect and bring data to the management meeting to be shared with a team. Data analysis is done either before the meeting or requested during the meeting as homework for next time. Performance monitoring activities are not necessarily based on statistical tools, but data availability and regular updates are important for quantitative and qualitative data to understand the current situation and risks. Once the indicators are agreed upon, the managers can request data collection from the assigned team member to ensure the monitoring of the focus areas" - "look, if you have indicators here, please, bring information, otherwise we change indicators, okay... if we cannot monitor the indicator, we need to replace it with something else" (Meeting 1213).

The main data sources are systems and employees. While systems are a source of numeric data, employees bring messages and qualitative information. Managers can decide on potential risk based on the reasoning provided and, on the contrary, raw numbers do not help - "I just brought figures, cannot comment" (Meeting 1024). Data without analysis and explanations are not sufficient to define risk and decide on mitigating measures. Company A does not have a risk register. Company $\mathrm{B}$ has a risk register, which is reviewed once per year. In the risk register, the identified risks are assessed and prioritized by likelihood and possible impact during the annual review, but the risks discussed in the management meetings are not referred to the risk register.

\subsubsection{Discussing risk-related deviations and obstacles}

Performance monitoring and information sharing within a team help manage risks only if decisions then follow. A lack of discussion and attention is equal to ignoring the risk, as mentioned during the meetings, "we were waiting and waiting, but no result appeared" (Meeting 1027); and "if you are 
not going to do anything why do we measure?" (Meeting 1114).

On the contrary, having a critical view and the questions asked help to identify potential risks even if the past data is in line with expectations: for example, "what can ruin your optimism in Klaipeda this week?" (Meeting 1024) or "what obstacles are there to doing this today?" (Meeting 1027). These questions challenge the initial expectations and make the team take a broader view and return to risk identification. In Company A, the managers allocate time to discuss the reasons for any deviations and obstacles. If actions are agreed upon, they are placed on the board. In Company B, the managers try to avoid discussions during their daily meetings; instead, they usually meet and discuss significant deviations or obstacles after the meetings in smaller teams. It is not clear how and when feedback is brought back to the management team.

\subsubsection{Addressing customer complaints}

The employees are authorized to answer and solve customer complaints, and they involve the managers only in exceptional cases. For example, a complaint from a well-known politician is understood to be a greater risk, as it can be followed by reputational issues if not resolved properly. An increased level of calls draws the management's attention and creates an opportunity to pick up on a signal by examining the nature of the questions received. In order to catch a signal from customer complaints, the manager must interact with the team and have an escalation path. During a meeting, the managers share the most important customer complaints with other managers and discuss the reasons behind the issue and its possible impact.

\subsubsection{Working with investigation/ inspection reports}

Information about upcoming audits or inspections is presented as a signal to the team and, afterward, findings from the report are shared and discussed. Annual auditing was not included in our research scope and we did not analyze this procedure. However, external inspections or investigations were mentioned during the meetings at both companies and treated as risks that need immediate attention"- "I have a signal that we just received the conclusion from the authorities about purchases, and they conclude breaching. Breaches related with technical specifications, not with purchasing procedures" (Meeting 0125).

By sharing the conclusions from these, the managers can warn the management team about the risks related to reputation and financial outcome; thus assessing and identifying risks in the processes that need management attention to prevent their repetition in the future. In addition to external inspections and audits, the managers plan internal process audits and report the findings to the team in Company A. In Company $\mathrm{B}$, the managers plan observations of practices in business units and share their views. It is assumed that internal audits and observations are management controls.

To sum up, risk assessment winds up with an aligned view on the need for mitigating and preventive actions based on the data collected about the problem; a discussion about the impact in terms of losses; a consideration of the possible impact for other functions; or the potential for repetition in future. 


\section{Journal of Contemporary Management Issues}

\subsection{Risk response practices}

Once problems and potential risks are identified and assessed, managers have to respond to them. First, they ensure that someone takes responsibility for executing the decision and ensuring it is followed up. Second, they execute the decided response to the risk - continue to monitor, act immediately to reduce the impact, or initiate improvements to prevent the problem from recurring in the future.

\subsubsection{Assigning responsibility}

Responsibility can be assigned based on function or an agreement. Projects and indicators have people assigned to them who are responsible for bringing information to the meeting. For example, if the responsibility to coordinate the management of the risk related to safety at work is assigned to the human resource management function, then a human resource manager will be following up on the implementation of decisions to minimize this specific risk. When a specific risk is not approached functionally, the responsibility for it is agreed upon within the management team based on context and availability. During the meeting, the managers remind each other about this by asking "who can take responsibility for this?" (Meeting 1017) or "who is going to proceed with this authorization matrix?" (Meeting 1114). Once the managers agree on responsibility and record it, they take tasks away with them and bring them to their teams after the meeting. This practice ensures accountability within the team and safeguards against an identified risk being left unattended.

In Company A, if a decision is made, the responsibility is assigned during the meeting. Sometimes the discussion ends without a decision and it is not clear who is responsible. In Company $\mathrm{B}$, the management team has the rule to refrain from making any decisions during the meeting and sometimes they do not identify who is responsible for further elaboration on an issue. In the risk mitigation plan, the responsibility for each action is assigned to someone who is expected to report on its implementation, but the CEO is responsible for reporting to the Board on the whole plan on a quarterly basis.

\subsubsection{Recording and reporting back}

In both companies, the managers report back to the management team about any tasks that were assigned in the previous meetings. The managers share responsibility for updating and bringing information to the management meeting. The managers remind each other to highlight important risk-related tasks on the board during the meeting: for example, "maybe we need some visual reminder" (Meeting 1121) or "can we put this task to analyze export documentation on the board?" (Meeting 1017). Recording tasks on the board helps to ensure follow-up. The managers train their teams to record and report on the tasks.

In company $\mathrm{B}$, the main risks are identified and risk ownership is assigned during the annual risk self-assessment workshop. The weekly or daily management meeting agenda and its content have a vague relationship with the risk register and the risk mitigation plan. Quarterly reporting on the implementation of the risk mitigation plan has been introduced.

\subsubsection{Reacting to problems, including firefighting}

The identified problems are approached when managers take actions to reduce the threat, such as risk mitigation and/or minimizing the consequences of a risk event. The CEOs of both companies expect their 
teams to learn from their own mistakes; however, initial "firefighting" is not always followed by a search for the root cause of the problem. The managers must be prepared to identify and solve problems, i.e., to deal with new emerging risks - "reaction is the same to everything that is new - but when we detect a problem, they understand that we need improvements" (Meeting 1024)

While dealing with problems and failures might be perceived as reactive, it can be converted to a proactive practice in two ways: first, "understanding the underlying causes and possible repetition in future" (M3) and second, a more comprehensive retrospective discussion is helpful to identify new risks by "learning from past mistakes” (M2). In Company A, the managers did more firefighting than problem-solving during the meetings, as they were talking more about risk events than about uncertainty about the future. In this company, industry-specific risks are defined and actions are aligned with legal requirements. The company uses insurance for the fleet to minimize the consequences of risk related to accidents and physical damage. Another risk-related indicator - safety incidents-is monitored constantly, reported on in management team meetings and followed with immediate actions in case of any incident or "near-miss". In Company B, risks that are identified during risk workshops are registered in the risk register and converted into an action plan that has to be implemented on time, and they are no longer treated as problems.

\subsubsection{Defining and improving processes, maintaining clarity}

Both companies work on process standardization and improvement. The practices related to defining and improving processes reduce deviations from that which is expected in operations. The managers involve the employees in the process improvement activities to understand the real problems and get their input regarding solutions: for example, "do we talk with drivers? We will never receive any improvement suggestions from employees if there are no meetings" (Meeting 1027).

These continuous improvement activities extend or even replace risk-mitigation plans and help develop proactive thinking, i.e., a risk mindset. In Company $\mathrm{B}$, operational excellence meetings are held on a weekly basis to review process improvements, while Company A reviews improvements during weekly performance meetings. After the solution is implemented, the managers can follow up on the outcome through monitoring activities. When there is no need to take immediate action regarding a potential risk, monitoring practices are switched on. The companies use process management and LEAN tools for continuous improvement activities at the operational level, represented by daily visual meetings and systematic problem-solving. Ensuring that someone is taking responsibility for and following up on the identified potential risk or otherwise dealing with a problem is critical to the continuity of the system.

In summary, managers use similar practices to identify, assess, and respond to risk on a daily basis in both companies, even though only one of them has any formally required risk management procedures and policies. These practices are interrelated and overlapping; thus, risk management is accomplished by a non-linear iterative process. Moreover, the formal risk management process is separated from daily management practices that managers use to deal with risk. In the case of external compliance requirements, they are perceived as 


\section{Journal of Contemporary Management Issues}

happening linearly, starting with risk identification during risk workshop and followed by risk assessment procedures, which are finalized through the implementation of the prepared risk mitigation plan, i.e., risk response practices. Even if formal risk management procedures are aligned at the strategic level but remain detached from the operational level, they do not become successful risk management practices but create additional bureaucracy for the management team.

This research challenges the strict sequence in which formal risk management practices are instilled in an organization without integration into everyday management practices and driven by the compliance focus. In reality, risk management practices are driven by the management's focus on achieving business objectives and performance management and are embedded in regular performance review meetings.

\section{DISCUSSION}

Through the literature analysis, three groups of risk management practices were defined: risk identification, risk assessment, and risk response. The findings revealed that the risk management practices that are part of management practices are interrelated with each other and "overlapping" in reality, thus forming a non-linear process with no clear beginning or end.

\subsection{Risk identification practices}

The core risk identification practice is to plan and monitor performance and potential risks. Planning and monitoring are two sides of the same coin that has two-fold importance for risk management - it generates signals identifying potential risks and risk events, and it helps to follow-up the implementation and outcome of risk-related decisions. Indeed, this practice generates input for risk identification; however, it also helps ensure awareness and share information related to the risk. Planning and monitoring are continuous practices at both the strategic and operational levels, unlike risk workshops or other formal practices conducted once per year or quarterly. This study extends the viewpoint of Palermo et al. (2017) that these measures are part of risk identification, relating it with regular performance review meetings at which the actual and expected results are compared and signals about risks are shared with the team. The observation of management meetings provided empirical evidence and extended the conceptual understanding, as per Maguire and Hardy (2013), of how managers align their perception of risk by meeting together and discussing performance regularly. While performance targets and key performance indicators are defined at the strategic level and are often based on experience and past information, managers are able to grasp new risks based on shared operational information and by questioning the existing knowledge when meeting daily as a team.

The analysis of risk identification practices revealed a paradox in which managers identify failures and potential risks but do not perceive this as a risk management practice in the management team, as it is not included in the formal risk management toolbox. Identification and assessment are often not separated when managers choose a focus area. After the problems and potential risks that need further attention are identified and responded to, follow-up is ensured through monitoring and this cycle never ends. 


\subsection{Risk assessment practices}

This study brings a new perspective to the view of Ring et al. (2016), Bednarek et al. (2019), and others that regulatory requirements push calculating practices as part of the standardized and auditable process. Additionally, standardized tools and procedures are expected to become risk management practices but the reality is different. In reality, nobody uses calculating practices for all hypothetical risks, but they make selective decisions that identify which risks and problems need deeper investigation. The findings of this study illustrate that managers are aware of uncertainties and risks. They regularly respond to a rapidly evolving context by making decisions at different levels, even though they may deny having a formal and complex risk assessment process. As Bromiley et al. (2015) noted, this explains the difference between objective measures and managers' subjective risk assessment. From a management perspective, the signals about a changing context and the ability to discuss it are more important than precise calculations in risk assessment.

The findings of this study provide an understanding that the business focus on the achievement of objectives and the ERM focus on the framework, procedures and controls constitute a potential source of miscommunication by separating risk and management into two separate systems. Instead of integrating conventional risk management tools into daily routines, a CEO and a management team may create an alternative practice: for example, discussing risk-related deviations and obstacles and related information instead of making probabilistic calculations. A risk event or failure requires action to minimize the consequences now and prevent repetition in the future. Mitigating and preventive actions are decided once the teams have collected information about the problem, thought about the impact of losses and nonmaterial effect on objectives, and discussed the possible impact on other functions and processes, in other words, by combining the quantitative and qualitative views. Based on findings, risk assessment often contributes to risk identification by revealing additional risks.

\subsection{Risk response practices}

This study brings a new perspective to responsibility-sharing in risk management as a part of risk response. Responsibility can be assigned to organizational actors based on their role or function; however, the findings revealed that identifying problems and risks is followed by ensuring that someone is taking responsibility and following up on the issue related to risk. This practice is an important link between risk identification, risk assessment, and risk response.

Based on the findings, the companies use process management and LEAN tools, i.e., continuous improvement activities and systematic problem solving as a long-term risk response practice. This research extends the view of application management controls as a risk response practice (Woods, 2008). Regular interactive management practices, which were discussed as risk identification practices, extend traditional management controls, i.e., investigations and auditing. In addition, recording the decision and reporting back is an important part of risk response to ensure follow-up on risk response within a team. The findings confirmed the relation between risk response and risk identification as the resolved issue returns to the monitoring stage, replacing the risk conclusion stage mentioned in the project risk management literature (Boban et al., 2003). This extends the 


\section{Journal of Contemporary Management Issues}

understanding of how risk response practices relate to the construction of the risk object in organizations, as per Bednarek et al. (2019).

Although reacting to the problem is often a short-term risk response, it can be converted into a long-term practice by analyzing the causality behind and applying a more comprehensive retrospective discussion, i.e., learning practices, as defined by Hardy et al. (2020). Based on the findings, the learning practices support the transition from short-term to long-term risk response.

\subsection{Overall risk management practices}

In general, this study confirms the previous research (Power, 2016; Kaplan and Mikes, 2016; Palermo et al., 2017) by revealing the interrelated risk management practices through which managers identify, assess, and respond to risk and extends it by establishing a relationship between risk and management practices that are not explicitly dedicated to risk management. Furthermore, this empirical research identified learning from failures as a supportive practice for risk management practices. Questioning the outcome and reflecting on it means opening the boundary of rationality for continuous improvement and providing the background for knowledge sharing and organizational learning. Although knowledge sharing and learning do not get much attention within risk management research, learning influences risk management in innovations through thinking about options and experimental processes (O'Connor et al., 2008). The findings of this study confirm the importance of learning from failures in risk management practices, adding to the research of Manuj and Mentzer (2019). Empirical evidence of risk management accomplishment through management practices reduces the ERM field fragmentation by bringing together theory and practice, as Hardy et al. (2020) suggested. Moreover, this study is responding to the call of McShane (2018) to step over the boundaries of the disciplinary field to understand how managers are involved in risk management every day.

\section{CONCLUSION}

This research addresses the call of ERM researchers (Bromiley et al., 2015; Power 2016; Hardy et al. 2020) to empirically analyze the role of managers in risk management and real risk work. This paper closes the gap by systematically and empirically investigating three sets of risk management practices: risk identification, risk assessment, and risk response, and providing an empirically grounded new perspective on how managers manage risks every day. Two different ways to manage risk can exist simultaneously in the same organization, i.e., formal ones and those accomplished through management practices that are not explicitly dedicated to risk management but can, nevertheless, be standardized and observable, for example, regular performance management meetings or continuous improvement workshops. Moreover, it also reveals learning from failures as an additional supportive risk management practice.

Business organizations' risk management practices form a non-linear process, so there is no clear beginning or end of the process. The business objectives and targets produced at the strategic level act as anchors for risk management through monitoring at the strategic management level and through daily operational issues (customer claims, escalations from the team, project management, daily planning, etc.). Likewise, regular performance reviews 
anchor risk management to the operational management level.

Risk management practices support strategy deployment only when connected to daily management practices. As suggested by Treven et al. (2019), a more holistic understanding of management practices is expected to have a long-term effect on the future development and resilience of business organizations. This study opens further avenues for research on the social construction of risk management in an organization by overcoming boundaries between disciplinary fields instead of exploring risk management practices through the lens of implementation of standardized tools.

Although risk management research is stepping outside the boundaries of finance, accounting, and crisis management, and elevating it to total risk management at the organizational level (Arena et al., 2010; Bromiley et al., 2015), most risk management studies (Palermo et al., 2017; Ring et al., 2016; Oliveira et al., 2018) are structured around a formalized risk management framework that is assigned to a risk management professional. This interdisciplinary research offers a new perspective on enterprise risk management and a meaningful contribution to bridging risk management theory with management practice.

\subsection{Limitations}

This study is limited to two cases. However, following Eisenhardt (2021), careful selection of sites and polarization criteria were used to enrich the contextual details for data interpretation. As this research was conducted in companies with regular performance management meetings, further research is recommended to explore what management practices are used to manage risks when managers do not have daily or weekly meetings.
Empirical data for this study were collected before COVID-19 pandemic crisis that no one could have foreseen. Nevertheless, empirical evidence of two different ways to manage risks in the same organization opens further avenues to explore how formal risk management implementation and management practices can be used to identify, assess, and respond to risks daily in the post-pandemic era.

The empirical study took place in Lithuania and did not explore any potential cultural impact on risk management. National culture may potentially affect risk management - risk perception and practices may vary across cultures with different levels of uncertainty avoidance, individualism, etc.. Therefore, further research is recommended to explore and compare how risk management is accomplished in different countries through management's daily practice.

\section{REFERENCES}

1. Arena, M., Arnaboldi, M., \& Azzone, G. (2010). The organizational dynamics of Enterprise Risk Management. Accounting, Organizations and Society 35, 659-675. https://doi.org/10.1016/j. aos.2010.07.003

2. Arena M., \& Arnaboldi, M. (2014). Risk and performance management: are they easy partners? Management Research Review, 37(2), 152 - 166. https://doi.org/10.1108/ MRR-08-2012-0180

3. Bednarek, R., Chalkias, K. \& Jarzabkowski, P. (2019), Managing risk as a duality of harm and benefit: A study of organizational risk objects in the global insurance industry, British Journal of Management, 32(1), 235-254. 


\section{Journal of Contemporary Management Issues}

4. Boban, M., Požgaj, Ž., \& Sertić, H. (2003). Strategies for successful software development risk management. Management: Journal of Contemporary Management Issues, 8(2), 77-91.

5. Boden, D. (1997). Temporal frames: Time and talk in organizations. Time \& Society, 6(1), 5-33. https://doi. org/10.1177/0961463X97006001001

6. Braun, V. \& Clarke, V. (2006). Using thematic analysis in psychology. Qualitative Research in Psychology, 3, 77 - 101. https://doi. org/10.1191/1478088706qp063oa

7. Bromiley, P., McShane, M., Nair, A., \& Rustambekov, E. (2015). Enterprise risk management: Review, critique, and research directions https//doi. org/10.1016/j.lrp.2014.07.005

8. Carmeli, A., \& Halevi, M.Y.(2009). How top management team behavioral integration and behavioral complexity enable organizational ambidexterity: The moderating role of contextual ambidexterity. The Leadership Quarterly 20, 207-218. https://doi.org/10.1016/j. leaqua.2009.01.011

9. Eisenhardt, K.M. (1989). Building Theories from Case Study Research. The Academy of Management Review, 14(4), 532-550.

10. Eisenhardt, K. M. (2021). What is the Eisenhardt Method, really? Strategic Organization, 19(1), 147-160. https:// doi.org/10.1177/1476127020982866.

11. Frigo, M. L., \& Anderson, R. J. (2014). Risk Management Framework: Adapt, don't adopt. Strategic Finance, 96(1), 49-53.

12. Hardy, C., Maguire, S., Power, M., \& Tsoukas, H. (2020). Organizing risk: organization and management theory for the risk society. Academy of
Management Annals, 14(2), 10321066 . https://doi.org/10.5465/ annals.2018.0110

13. Hubbard, D.W. (2009). The failure of risk management: why it's broken and how to fix it. John Wiley \& Sons.

14. Johannessen, J., Olaisen, J., \& Olsen, B. (2001). Mismanagement of tacit knowledge: The importance of tacit knowledge, the danger of information technology, and what to do about it. International Journal of Information Management, 21(1), 3-20. https://doi. org/10.1016/S0268-4012(00)00047-5

15. Kahneman, D. (2011). Thinking, fast and slow. Palgrave Macmillan.

16. Kaplan R.S. and Mikes, A. (2016). Risk Management - the Revealing Hand. Journal of Applied Corporate Finance. 28(1), 8-18. https://doi. org/10.1111/jacf.12155

17. Maguire, S., \& Hardy, C. (2013). Organizing processes and the construction of risk: A discursive approach. Academy of Management Journal, 56(1), 231-255. https://doi. org/10.5465/amj.2010.0714

18. Manuj, I. \& Mentzer, J.T. (2008). Global supply chain risk management strategies. International Journal of Physical Distribution \& Logistics Management, 38 (3), 192-223. https:// doi.org/10.1108/09600030810866986

19. McShane, M. (2018), Enterprise risk management: history and a design science proposal, Journal of Risk Finance, 19(2), 137-153. https://doi. org/10.1108/JRF-03-2017-0048

20. Mikes, A. \& Kaplan, R.S. (2013). Towards a Contingency Theory of Enterprise Risk Management. AAA 2014 Management Accounting Section (MAS) Meeting Paper. 
Available at SSRN: https://ssrn.com/ abstract $=2311293$

21. Nair, A., Rustambekov, E., McShane, M., \& Fainshmidt, S. (2014). Enterprise risk management as a dynamic capability: A test of its effectiveness during a crisis. Managerial and Decision Economics, 35(8), 555-566. https://doi.org/10.1002/mde.2641

22. O'Connor, G. C., Ravichandran, T., \& Robeson, D. (2008). Risk management through learning: Management practices for radical innovation success. The Journal of High Technology Management Research, 19(1), 70-82. $\quad$ https://doi.org/10.1016/j. hitech.2008.06.003

23. Oliveira, K., Méxas, M., Meiriño, M., \& Drumond, G. (2018). Critical success factors associated with the implementation of enterprise risk management. Journal of Risk Research, 1-16. https://doi.org/10.1080/13669877.2018 .1437061

24. Osman, O.M., \& Mahmoud, A.M. (2018). Managing Risks during Strategy Implementation. IJIRMPS, 6(6), https://www.ijirmps.org/papers/2018/6/330.pdf

25. Palermo, T., Power, M., \& Ashby, S. (2017). Navigating institutional complexity: The production of risk culture in the financial sector. Journal of Management Studies, 54(2), 154-181. https://doi.org/10.1111/joms.12241

26. Pidgeon, N. (1998). Risk assessment, risk values and the social science programme: why we do need risk perception research. Reliability Engineering \& System Safety, 59(1), 5-15. https://doi.org/10.1016/ S0951-8320(97)00114-2
27. Power, M. (Ed.). (2016). Riskwork: Essays on the organizational life of risk management. Oxford University Press.

28. Prioteasa, A. L., Chicu, N., Bugheanu, A. M., \& Dinulescu, R. (2020). Risk Management Practices in Small and Medium Enterprises: Evidence from Romania. Management and Economics Review, 5(1), 1-15.

29. Ring, P. J., Bryce, C., McKinney, R., \& Webb, R. (2016). Taking notice of risk culture - the regulator's approach. Journal of Risk Research, 19(3), 364-387. https://doi.or g/10.1080/13669877.2014.983944

30. Roethlisberger, F. J. (1941). Management and morale.

31. Roethlisberger, F. J., \& Dickson, W. J. (2003). Management and the worker Psychology Press.

32. Slack, N., Chambers, S., Johnston, R. (2007). Operations Management. Prentice Hall.

33. Taleb, N. N. (2012). Antifragile: Things that gain from disorder. Random House Incorporated.

34. Tereso A., Ribeiro, P., Fernandes, G., Loureiro, I. \& Ferreira, M. (2019). Project Management Practices in Private Organizations. Project Management Journal, 50(I) 6-22. https://doi. org/10.1177/8756972818810966

35. Treven, S., Uršič, D., \& Rashad, W. (2019). How management tools holistically support enterprises' operation in supply chains? Management: Journal of Contemporary Management Issues, 24(1), 1-20. https://doi. org/10.30924/mjcmi.24.1.1

36. Tversky, A., \& Kahneman, D. (1974). Judgment under uncertainty: Heuristics and biases. Science, 185(4157), 1124-1131. 


\title{
Journal of Contemporary Management Issues
}

37. Tversky, A., \& Fox, C. R. (1995). Weighing risk and uncertainty. Psychological Review, 102(2), 269.

38. Wardman, J. K., \& Mythen, G. (2016). Risk communication: Against the gods or against all odds? problems and prospects of accounting for black swans. Journal of Risk Research, 19(10), 1220-1230. https:// doi.org/10.1080/13669877.2016.12620 02
39. Woods, M. (2008). Linking risk management to strategic controls: a case study of Tesco plc. International Journal of. Risk Assessment and Management, 7(8), 1074-1088. https:// doi.org/10.1504/IJRAM.2007.015295

40. Zinn, J. O. (2006). Recent developments in sociology of risk and uncertainty. Historical Social Research/ Historische Sozialforschung, 275-286. https://www.jstor.org/stable/20762130

\section{EMPIRIJSKO ISTRAŽIVANJE PRAKSE MENADŽMENTA RIZIKA}

\begin{abstract}
Sažetak
U istraživanju menadžmenta rizika, upravljanje poznatim rizicima i pomoć poduzećima da predvide nove rizike područje su rada specijaliziranih eksperata. U praksi, menadžment rizika se često percipira kao skupina formalnih alata i procedura, koje je potrebno delegirati profesionalcima. Usprkos ovakvoj općoj percepciji rizika, top menadžeri, menadžer odjela i drugi visoko pozicionirani ili linijski menadžeri trebaju se dnevno baviti pitanjima, povezanim s rizikom. Stoga su i sami, bez obzira jesu li toga svjesni, uključeni u praksu upravljanja rizikom. U ovom se članku želi analizirati menadžerska uključnost u menadžment rizika, putem empirijskog istraživanja identifikacije, procjene i odgovora na rizik. Na temelju tematske analize opservacijskih, kao i podataka dobivenih intervjua, utvrđene su menadžerske prakse korištene za upravljanje rizicima, pri čemu je menadžment rizika definiran kao nelinearni proces, utemeljen na strateškoj i operativnoj razini, a kojeg podržava učenje iz grešaka. Dva različita pristupa menadžmentu rizika mogu koegzistirati u organizaciji, kao rezultat formalne implementacije korporacijskog upravljanja rizikom.
\end{abstract}

Ključne riječi: praksa upravljanja rizikom, korporacijsko upravljanje rizikom, rizik, menadžeri, menadžerska praksa. 